\title{
Estudo eletroquímico do processo de eletrooxidação da amitriptilina empregando sensor a base de pasta de carbono contendo DNA imobilizado em matriz inorgânica
}

\section{Electrochemical study of oxidation process of amitriptiline using sensor based on carbon paste containing immobilized DNA on inorganic matrix}

\author{
João Paulo Marco'; Keyller Bastos Borges¹; César Ricardo Teixeira Tarley²; Emerson Schwingel \\ Ribeiro ${ }^{3}$; Arnaldo César Pereira ${ }^{1}$
}

\begin{abstract}
Resumo
No presente trabalho foi estudado o comportamento voltamétrico e o processo de eletrooxidação de amitriptilina (AMT) em sensor eletroquímico baseado em pasta de carbono contendo DNA imobilizado em matriz inorgânica preparada pelo processo sol-gel $\left(\mathrm{SiO}_{2} / \mathrm{Al}_{2} \mathrm{O}_{3} / \mathrm{Nb}_{2} \mathrm{O}_{5}\right)$. Pelo método de Laviron verificou-se que o processo de eletrooxidação da AMT é irreversível e com alta velocidade de transferência de elétrons, indicando que o sensor proposto é cineticamente viável para promover a eletroeletrooxidação da AMT. O estudo do efeito do $\mathrm{pH}$ sobre o processo de eletrooxidação da AMT apresentou comportamento nernstiniano $(0,059 \mathrm{~V} / \mathrm{pH})$ sugerindo que o mesmo envolve a transferência de 1 próton e 1 elétron.
\end{abstract}

Palavras-chave: Antidepressivo. Comportamento eletroquímico. Processo de oxidação. GRF/DNA/ $\mathrm{SiO}_{2} / \mathrm{Al}_{2} \mathrm{O}_{3} / \mathrm{Nb}_{2} \mathrm{O}_{5}$.

\begin{abstract}
In the present work the voltammetric behavior and the electroxidation process of amitriptiline (AMT) in electrochemical sensor based on carbon paste containing DNA immobilized on the inorganic matrix prepared by sol-gel process $\left(\mathrm{SiO}_{2} / \mathrm{Al}_{2} \mathrm{O}_{3} / \mathrm{Nb}_{2} \mathrm{O}_{5}\right)$. The method of Laviron verified that the electroxidation process of AMT is irreversible and high speed of electron transfer. The study of the oxidation of AMT and influence of $\mathrm{pH}$ showed slope of $0.059 \mathrm{~V} / \mathrm{pH}$ (similar the nernstian system: $0.0592 \mathrm{~V} / \mathrm{pH}$ ) suggesting that it involves the transfer of one proton and one electron.
\end{abstract}

Keywords: Antidepressant. Electrochemical behavior. Oxidation process. GRF/DNA/SiO $/ \mathrm{Al}_{2} \mathrm{O}_{3} / \mathrm{Nb}_{2} \mathrm{O}_{5}$

\footnotetext{
${ }^{1}$ Aluno de Mestrado- Departamento de Ciências Naturais, Universidade Federal de São João del Rei (UFSJ), Campus Dom Bosco, Praça Dom Helvécio 74, Fábricas, 36301-160, São João del Rei, MG, Brasil.

${ }^{1}$ Professor Adjunto - Departamento de Ciências Naturais, Universidade Federal de São João del Rei (UFSJ), Campus Dom Bosco, Praça Dom Helvécio 74, Fábricas, 36301-160, São João del Rei, MG, Brasil. arnaldo@ufsj.edu.br

${ }^{2}$ Professor Adjunto - Departamento de Química, Universidade Estadual de Londrina (UEL), Centro de Ciências Exatas, Rodovia Celso Garcia Cid PR 445 Km 380, 86050-482, Londrina, PR, Brasil.

${ }^{3}$ Professor Adjunto - Departamento de Química Inorgânica, Instituto de Química, Universidade Federal do Rio de Janeiro (UFRJ), 21941-909, Rio de Janeiro, RJ, Brasil.
} 


\section{Introdução}

Amitriptilina pertence ao grupo dos azepinicos, e é um composto farmacêutico amplamente utilizado devido a sua atividade antipsicótica, sedativa e propriedades analgésicas. Atua controlando distúrbios psicomotores como: agitação, excitação, estados hipercinéticos e agressivos (ROMEIRO et al., 2003; SABIN et al., 2004) .

Devido ao fármaco ser amplamente indicado para tratamento não só como uma substância antipsicótica, verifica-se que seu monitoramento em formulações farmacêuticas é de fundamental importância. Neste ponto, o desenvolvimento de plataformas eletroquímicas se figura promissor para detecção deste fármaco, especialmente ao se considerar a baixa atividade eletroativa do fármaco em eletrodos a base de carbono.

O uso de DNA como elemento modificador de eletrodos tem sido reportado na literatura principalmente devido a diferença do comportamento eletroquímico do analito de interesse na presença do DNA (WEI, et al., 2014). Adicionalmente, também pode atuar com materiais pré-concentradores de AMT por meio do uso de eletrodos de grafite modificados com DNA (BIRYOL et al., 1996). De acordo com este trabalho e sabendo-se que materiais a base de pasta de carbono tem sido empregados em eletroquímica no desenvolvimento de sensores e biossensores devido a algumas características importantes, as quais se destacam: alta versatilidade de modificação de sua superfície com outros materiais inorgânicos, baixa corrente de fundo, baixo custo de construção, modificação conveniente, ampla janela de potencial, inercial química e facilidade de renovação da superfície. Pasta de carbono é uma mistura de grafite em pó com um líquido orgânico que é imiscível em contato com a solução aquosa. A superfície dos eletrodos de pasta de carbono é muito complexa, com muitas possibilidades de interação (PEREIRA et al., 2002; PAVAN et al., 2005).

Uma das principais vantagens de pasta de carbono para a construção de sensores e biossensores é que esses eletrodos possibilitam a modificação interna do material eletródico, diferentemente do que ocorre com os eletrodos sólidos convencionais, em que a modificação ocorre apenas na superfície. Assim, em estudos envolvendo eletrodos de pasta é possível a co-imobilização de enzimas, cofatores, mediadores, estabilizadores resultando numa configuração de eletrodos sem a necessidade de adição de reagentes durante a determinação (PEREIRA et al., 2002).

Uma melhoria considerável no preparo de sensores à base de materiais carbonáceos com DNA pode ser obtida fazendo uso de matrizes inorgânicas no preparo do compósito. Os eletrodos modificados com materiais inorgânicos incluindo óxidos mistos, zeólitas, fosfatos, $\gamma$-alumina e outros tipos atualmente formam uma nova classe de eletrodos quimicamente modificados e são utilizados geralmente com o objetivo de aumentar a estabilidade das espécies eletroativas imobilizadas. Esta melhoria ocorre devido ao caráter ácido destes materiais inorgânicos que podem apresentar interações ácido-base de Brønsted com o DNA (MARCO, et al., 2013).

A síntese e a caracterização da matriz inorgânica $\mathrm{SiO}_{2} / \mathrm{Al}_{2} \mathrm{O}_{3} / \mathrm{Nb}_{2} \mathrm{O}_{5}$ foi recentemente publicada e investigada como um novo material préconcentrador de íons Cd(II) em solução (COSTA, et al., 2011), mostrando a exelente característica ácida desse material, e que pode ser usado nesse trabalho. De acordo com o exposto, este estudo tem como objetivo caracterizar eletroquimicamente o sensor a base de pasta de nanotubos de carbono contendo DNA imobilizado em $\mathrm{SiO}_{2} / \mathrm{Al}_{2} \mathrm{O}_{3} / \mathrm{Nb}_{2} \mathrm{O}_{5}$ como matriz inorgânica e avaliar o processo de eletrooxidação de AMT sobre este sensor.

\section{Materiais e Métodos}

\section{Reagentes e soluções}

Grafite em pó puro e Fosfato de sódio monobásico anidro foram obtidos da $\operatorname{Synth}^{\circledR}$ (Diadema, Brasil). DNA de esperma de arenque, cloridrato de 
amitriptilina (AMT), hidróxido de sódio, ácido nítrico e óleo mineral foram adquiridos da SigmaAldrich $^{\circledR}$ (St. Louis, MO, EUA). Cloreto de potássio foi obtido da Sial ${ }^{\circledR}$ (São Paulo, Brasil). Fosfato de sódio bibásico foi adquirido da Vetec ${ }^{\circledR}$ (Rio de Janeiro, Brasil). O material inorgânico $\left(\mathrm{SiO}_{2} / \mathrm{Al}_{2} \mathrm{O}_{3} / \mathrm{Nb}_{2} \mathrm{O}_{5}\right)$, obtida via processo sol-gel, foi preparada de acordo com o procedimento previamente descrito anteriormente (COSTA, et al., 2011). Este material foi fornecido pelo Prof. Dr. Emerson S. Ribeiro da Universidade Federal do Rio de Janeiro e será denominado SiAlNb.

Todos os demais reagentes utilizados foram de grau analítico e suas soluções preparadas em água destilada e deionizada utilizando sistema Millipore Milli-Q (resistividade $>18 \mathrm{M} \Omega \mathrm{cm}^{-1}, 25^{\circ} \mathrm{C}$ ).

\section{Instrumentação e célula eletroquímica}

As medidas eletroquímicas foram realizadas num potenciostato/galvanostato modelo PGSTAT12 da Ecochemie acoplado a um microcomputador contendo o software GPES 4.9, empregando uma célula com tampa de PVC contendo seis orifícios: três para os eletrodos, um para entrada, um para saída de gás $\left(\mathrm{N}_{2}\right.$ de alto grau de pureza) e um para adição de reagentes.

O eletrodo saturado de prata/cloreto de prata $(\mathrm{Ag} / \mathrm{AgCl})$, fornecido pela Metrohm ${ }^{\circledR}$, contendo $3 \mathrm{~mol} \mathrm{~L}^{-1}$ de $\mathrm{KCl}$ foi empregado como referência, e uma espiral de platina (construído no próprio laboratório) como o eletrodo auxiliar.

O eletrodo de trabalho utilizado foi construído no próprio laboratório. Este dispositivo é basicamente um tubo de vidro de $15 \mathrm{~cm}$ de comprimento contendo um fio de níquel/cromo e na base um disco de platina com uma cavidade inferior com $4 \mathrm{~mm}$ de diâmetro interno e $1 \mathrm{~mm}$ de profundidade para a inserção da pasta a base de material carbonáceo. A área geométrica deste eletrodo empregada para a obtenção das densidades de corrente é de $0,12 \mathrm{~cm}^{2}$.
O pH final das soluções tampão foram determinados por um pHmetro Digimed DM-20 e ajustado com soluções $1 \mathrm{~mol} \mathrm{~L}^{-1}$ de $\mathrm{HCl}$ ou $1 \mathrm{~mol}$ $\mathrm{L}^{-1}$ de $\mathrm{NaOH}$.

Antes de cada experimento, a solução de trabalho foi borbulhada com $\mathrm{N}_{2}$, por aproximadamente 10 minutos e, durante a realização do mesmo, o fluxo de gás foi mantido apenas sobre a superfície da solução.

\section{Preparação dos eletrodos de trabalho}

Para a imobilização do DNA na superfície da matriz de sílica $\left(\mathrm{SiO}_{2} / \mathrm{Al}_{2} \mathrm{O}_{3} / \mathrm{Nb}_{2} \mathrm{O}_{5}\right), 320 \mathrm{mg}$ de sílica foram adicionados em $60 \mathrm{~mL}$ de uma solução de DNA em concentração igual a 0,6 $\mathrm{mg} \mathrm{mL} \mathrm{mL}^{-1}$ preparada em solução tampão fosfato 0,1 mol L-1 pH 7,0, permanecendo esta solução sob agitação mecânica durante 15 min e após esta etapa, $12 \mathrm{~h}$ em repouso para adsorção do componente biológico na matriz. Logo após, realizou-se a filtração e posteriormente procedeu-se a secagem deste material (sílica com DNA imobilizado) em temperatura ambiente, a qual foi denominada de SiAlNb-DNA. Após o processo de secagem preparou-se a pasta de carbono contendo o material SiAlNb-DNA previamente preparada. Esta pasta era constituída por uma massa total de $60 \mathrm{mg}$ numa mistura utilizando a proporção $1: 1(\mathrm{~m} / \mathrm{m})$ entre a SiAlNb-DNA e o grafite em pó com óleo mineral. Misturavam-se bem os materiais até a sua completa homogeneização e, introduzia-se na cavidade inferior do tubo de vidro descrito na seção anterior, obtendo o eletrodo de pasta de carbono e sílica modificada com DNA, a qual foi denominada de GRF-SiAlNb-DNA para estudos contendo o analito AMT.

Estudo do comportamento eletroquímico do dispositivo GRF-SiAlNb-DNA na ausência e presença de $A M T$

O comportamento eletroquímico do biossensor GRF-SiAlNb-DNA foi avaliado por VC na ausência e presença de AMT. Para fins de comparação, 
também foram obtidos VCs com eletrodos de trabalho (sensores ou biossensores) preparados à base de GRF, GRF-SiAlNb e GRF-DNA na ausência e presença de $100 \mu \mathrm{mol} \mathrm{L}{ }^{-1}$ AMT. Todos os voltamogramas foram obtidos em solução 0,1 mol L-1 de tampão fosfato $(\mathrm{pH} 7,0)$ a $10 \mathrm{mVs}^{-1}$.

Estabilidade operacional do biossensor GRFSiAlNb-DNA

Foram realizados estudos quanto à estabilidade operacional do biossensor através de voltamogramas cíclicos. Cem voltamogramas foram obtidos com um mesmo eletrodo a base de GRF-SiAlNb-DNA no monitoramento de 1 mmol.L-1 de AMT, realizados a $10 \mathrm{mVs}^{-1} \mathrm{em}$ solução 0,2 mol. $L^{-1}$ de tampão fosfato $(\mathrm{pH} 7,5)$.

Processo de eletrooxidação do componente biológico no sensor proposto

Informações sobre o processo de oxirredução do componente biológico (DNA) imobilizado sobre a matriz da SiAlNb, na presença do pó de grafite (pasta de carbono) como matriz condutora foram adquiridas através da avaliação de voltamogramas cíclicos obtidos em diferentes velocidades de varredura, $v$, utilizando-se $10,0 \mathrm{~mL}$ de solução $0,2 \mathrm{~mol} \mathrm{~L}^{-1}$ de tampão fosfato $\mathrm{pH}$ 7,5. Os parâmetros cinéticos foram determinados com relação ao coeficiente de transferência de elétrons, $\alpha$, a constante de velocidade de transferência de elétrons, $k$ e o número de elétrons envolvidos, $n$, ou seja, o numero de elétrons envolvido no processo redox do DNA na ausência do analito de interesse.

\section{Estudo do processo de oxidação da AMT utilizando o biossensor GRF-SiAlNb-DNA}

Informações sobre a oxidação da AMT na superfície do biossensor GRF-SiAlNb-DNA constituído por uma mistura utilizando a proporção 1:1 (m/m) entre a SiAlNb-DNA (na concentração de $0,6 \mathrm{mg} \mathrm{mL}^{-1}$ de DNA) e o GRF foram adquiridas através da avaliação de voltamogramas cíclicos obtidos em diferentes $v$, utilizando $100 \mu \mathrm{mol} \mathrm{L}-1$ de AMT preparados em solução tampão fosfato $0,2 \mathrm{~mol} \mathrm{~L}^{-1}(\mathrm{pH} 7,5)$.

\section{Resultados}

Estudo do comportamento eletroquímico do eletrodo GRF-SiAlNb modificado e não modificado com DNA na ausência e presença do analito AMT

Para avaliar a atividade eletrocatalítica do biossensor GRF-SiAlNb-DNA, voltamogramas cíclicos foram obtidos com este dispositivo no intervalo de potencial de 0,3 a 1,4 V vs. $\mathrm{Ag} / \mathrm{AgCl}$ na ausência e presença de AMT. (Figura 1).

$\mathrm{Na}$ Figura 1 (a), dois picos anódicos foram detectados em potenciais de 0,8 e $1,11 \mathrm{~V}$ para o sensor GRF-SiAlNb-DNA. Esses picos podem ser atribuídos à oxidação de resíduos das bandas nitrogenadas guanina e adenina do DNA, respectivamente (BRETT at al., 1998; ZHENG et al., 2009; CALISKAN et al., 2009; WANG et al., 2001). Quando comparado ao voltamograma cíclico obtido com eletrodo de trabalho preparado a base de GRF-SiAlNb (ausência de DNA), foi possível observar que nesse caso não ocorreu nenhum processo faradaico no intervalo de potencial estudado, sendo este um resultado esperado.

Na Figura 1(b) é possível observar um pico de oxidação da AMT, evidenciando a electroatividade do fármaco no sensor GRF-SiAlNb-DNA. A fim de observar o efeito catalítico do DNA na oxidação da AMT, voltamogramas cíclicos foram obtidos empregando os sensores GRF-SiAlNb e GRFSiAlNB-DNA (Figura 1c). É possível observar um aumento um ligeiro deslocamento de potencial para regiões menos positivas do pico de oxidação do analito na presença do DNA, sugerindo assim, um efeito catalítico do DNA no processo de eletrooxidação do analito. 
Figura 1 (a) - Voltamogramas cíclicos obtidos com os seguintes biossensores e sensores: (1) GRFSiAlNb e (2) GRF-SiAlNb-DNA na ausência de AMT; (b) biossensor GRF-SiAlNb-DNA na ausência e presença de $100 \mu \mathrm{mol} \mathrm{L}{ }^{-1}$ de AMT e (c) sensor GRF-SiAlNb e biossensor GRF-SiAlNb-DNA na presença de $100 \mu \mathrm{mol} \mathrm{L}^{-1}$ de AMT. Experimentos foram realizados em solução tampão fosfato $0,1 \mathrm{~mol}$ $\mathrm{L}^{-1} \mathrm{pH} 7,0$ a $v=10 \mathrm{mVs}^{-1}$ no intervalo de potencial de 0,3 a $1,4 \mathrm{~V}$ vs. $\mathrm{Ag} / \mathrm{AgCl}$.
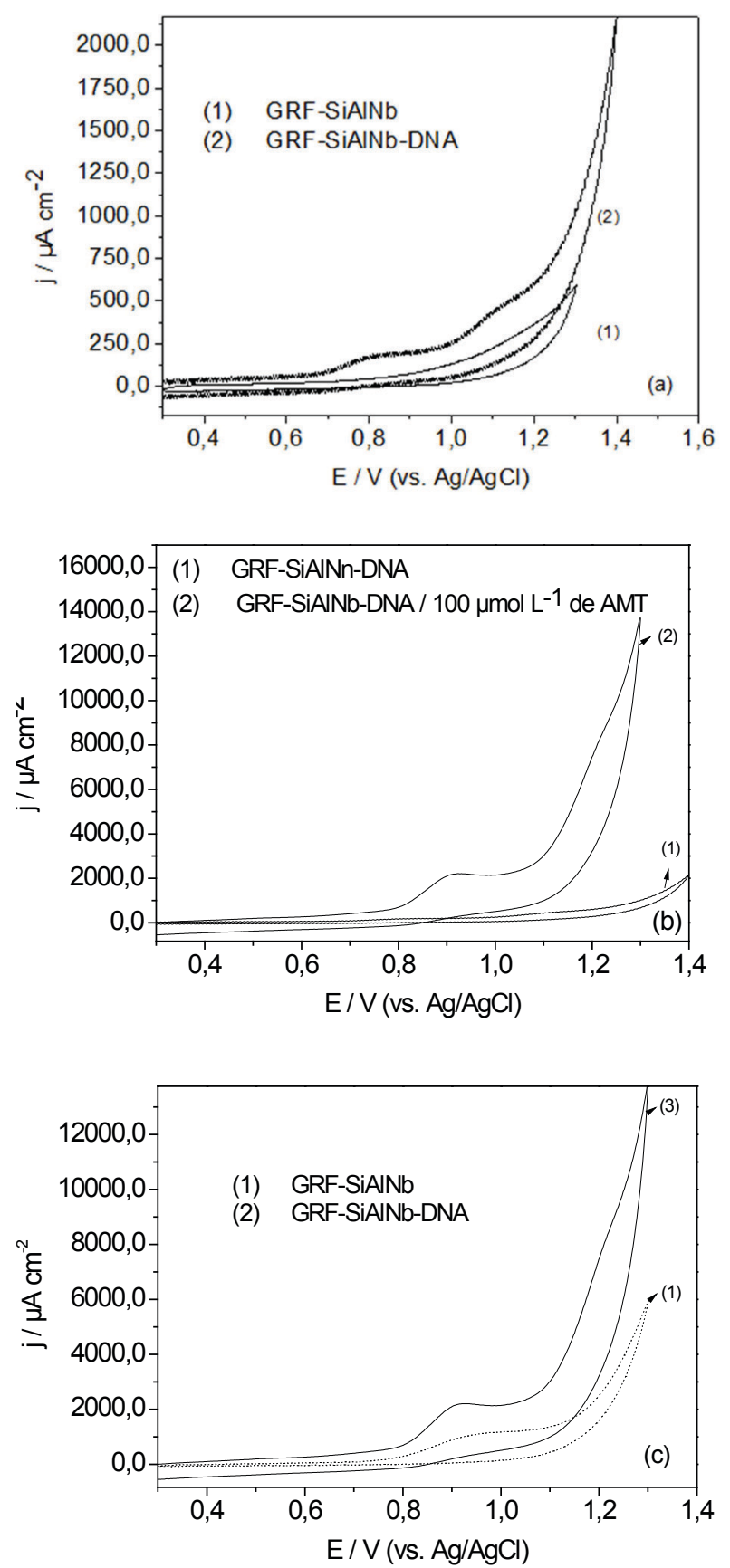

Fonte: Os autores
Estabilidade operacional do biossensor GRFSiAlNb-DNA

A estabilidade operacional do sensor desenvolvido para determinação de AMT foi avaliada por meio de 100 ciclos de varredura do potencial entre 0,3 a $1,2 \mathrm{~V}$ (voltametria cíclica), utilizando o sensor GRF-SiAlNb-DNA. Assim, a estabilidade da Ipa (intensidade de corrente de pico anódico) para o monitoramento de $1 \mathrm{mmol} \mathrm{L}^{-1}$ de AMT em solução tampão fosfato $0,2 \mathrm{~mol} \mathrm{~L}^{-1} \mathrm{pH} 7,5$ foi investigada.

O valor da resposta analítica encontrada inicialmente foi de $6466 \mu \mathrm{A} \mathrm{cm}^{-2}$ (TABELA 1) e os demais voltamogramas obtidos mostraram estabilidade do sinal da corrente de pico anódica até pelo menos 80 ciclos. A partir desta ciclagem, o nível da corrente de pico apresentou uma queda na intensidade, menor que 5\%, indicando uma pequena lixiviação do componente biológico da superfície do eletrodo para a solução tampão. Também, a pequena queda de intensidade de corrente a vários ciclos redox, pode ocorrer devido ao intumescimento da pasta de carbono, dificultando a transferência de elétrons entre os diferentes componentes. Embora ocorra uma pequena perda de sinal analítico, o sensor pode ser utilizado por várias horas, indicando forte interação do DNA com a matriz inorgânica e carbonácea. Importante lembrar, que o nível de perda na intensidade de corrente é menor do que em outros eletrodos a base de pasta de carbono relatados na literatura. Além disso, uma grande vantagem do emprego da pasta de carbono é a sua renovação quando necessário.

Tabela 1 - Intensidade da corrente de pico anódica (Ipa) para o biossensor GRF-SiAlNb-DNA após sucessivos voltamogramas cíclicos obtidos em solução tampão fosfato $0,2 \mathrm{~mol} \mathrm{~L}^{-1} \mathrm{pH} 7,5$ a 10 $\mathrm{mVs}^{-1}$ na presença de $1 \mathrm{mmol} \mathrm{L}^{-1}$ de AMT

\begin{tabular}{cccccc}
\hline Ciclos & 20 & 40 & 60 & 80 & 100 \\
\hline$j p a\left(\mu \mathrm{A} \mathrm{cm}^{-2}\right)$ & 6466 & 6458 & 6433 & 6416 & 6158 \\
\hline
\end{tabular}

Fonte: Os autores 
Estudo da eletrooxidação de AMT por meio do compósito GRF-SiAlNb-DNA

Com o intuito de estudar a cinética de transferência de elétrons entre o DNA no compósito GRF-SiAlNb e o analito AMT, foram estimados os parâmetros: $\alpha$ (coeficiente de transferência de elétrons), $\kappa$ (constante de velocidade de transferência de elétrons) e $n e$ (numero de elétrons) para a catalise com a espécie eletroativa de interesse. Informações sobre o processo de eletrooxidação foram obtidas através da análise da corrente de pico anódica, Ipa, por voltamogramas cíclicos deste dispositivo em solução contendo $1 \mathrm{mmol} \mathrm{L}^{-1}$ de AMT em solução tampão fosfato $0,2 \mathrm{~mol} \mathrm{~L}^{-1} \mathrm{pH} 7,5$.

De acordo com o modelo teórico de Andrieux e Sevéant (ANDRIEUX et al., 1978), a Ip é dependente da raiz da velocidade de varredura, $v^{1 / 2}$, para um processo irreversível conforme a Equação 1:

$$
I_{p}=0,0496 F A C_{R} D_{R}^{\frac{1}{2}}\left(\frac{F v}{R T}\right)^{\frac{1}{2}}
$$

Sendo que $C_{o}$ é a concentração do analito, $D_{o}$ é o coeficiente de difusão do analito na solução, $F$ a constante de Faraday. Por fim, $R$ e $T$ são: a constante dos gases e a temperatura, respectivamente.

Desta forma, foi possível estabelecer uma relação linear entre a Ip versus $v^{1 / 2}$ (Figura 2), indicando que a etapa limitante do processo de eletrooxidação é controlada por difusão (LAVIRON, 1982; LAVIRON, 1979).

Certamente, a característica porosa da matriz inorgânica preparada via processo sol-gel (COSTA, et al., 2011) influencia o processo de difusão e assim, os íons do eletrólito suporte (sistema tampão fosfato) não podem difundir facilmente para manter a eletroneutralidade da superfície do eletrodo. Além disso, nenhum decréscimo na corrente de pico após vários ciclos (Tabela 1) foi observado, indicando que o DNA, o qual possui várias bases nitrogenadas em sua estrutura, está fortemente adsorvido sobre a matriz SiAlNb (a qual atua como um ácido de Lewis). Assim, embora haja esta forte adsorção entre o DNA e a matriz inorgânica, os estudos indicam que há uma correlação linear entre a corrente de pico e a raiz quadrada da velocidade de varredura (dado não apresentado) sugerindo um processo redox controlado por difusão.

Figura 2 - Dependência entre a corrente de pico pela função da raiz quadrada da velocidade de varredura obtida para a catálise da AMT utilizando GRF-SiAlNbDNA. Experimento realizado em solução tampão fosfato $0,2 \mathrm{~mol} \mathrm{~L}^{-1} \mathrm{pH} 7,5$.

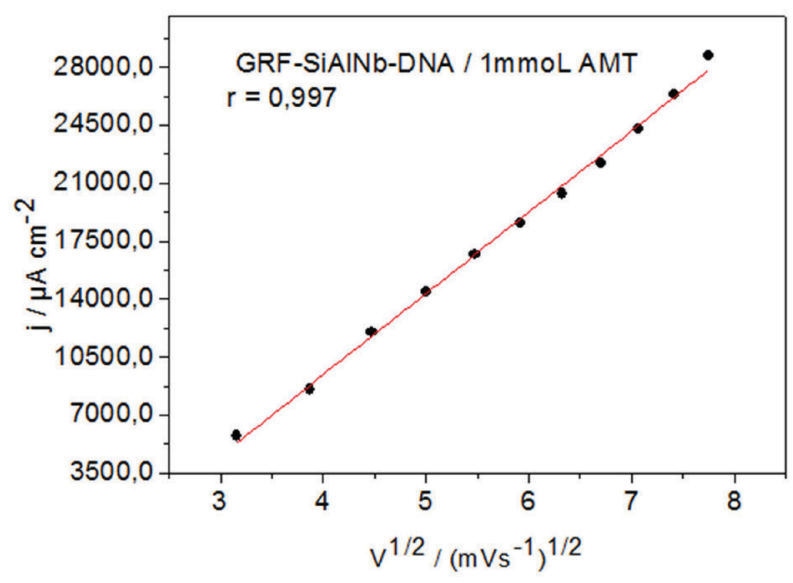

Fonte: Os autores

Como é esperado para um sistema irreversível, a Ip é dependente de $v^{1 / 2}$, e, portanto, o número de elétrons, $n$, envolvido na reação global de eletrooxidação da AMT pode ser obtido a partir do coeficiente angular do gráfico Ip versus $v^{1 / 2}$ de acordo com a Equação 2, a qual caracteriza um sistema totalmente irreversível controlado por difusão (BARD et al, 2001):

$$
\mathrm{I}_{\mathrm{p}}=\left(2,99 \mathrm{x} 10^{5}\right)\left[(1-\alpha) \mathrm{n}_{\mathrm{a}}{ }^{1 / 2} \mathrm{n} \mathrm{A} \mathrm{C}_{0}{ }^{*} \mathrm{D}_{0}{ }^{1 / 2} v^{1 / 2}\right.
$$

onde Ip é a corrente de pico, $n$ é o número total de elétrons envolvidos na reação, $\alpha$ é o coeficiente de transferência eletrônica, $n_{a}$, o número de elétrons 
envolvidos na etapa determinante da reação, $D_{0}$, o coeficiente de difusão da espécie eletroativa $\left(\mathrm{cm}^{2}\right.$ $\left.\mathrm{s}^{-1}\right), A$, a área do eletrodo, $C_{0}^{*}$, a concentração da espécie eletroativa no seio da solução $\left(\mathrm{mol} \mathrm{cm}^{-3}\right)$ e $v$, a velocidade de varredura. De acordo com a literatura (DUARTE et al, 2014a), o valor de $D_{0}$ para a AMT é igual a $4,14 \times 10^{-5} \mathrm{~cm}^{2} \mathrm{~s}^{-1}$. Entretanto, antes de se obter o número total de elétrons envolvidos na reação de eletrooxidação de AMT, foi necessário calcular o valor de $\left[(1-\alpha) n_{\mathrm{a}}\right]$, a partir da Equação 3:

$$
(1-\alpha) n_{a}=\frac{47,7 \mathrm{mV}}{E_{p}-E_{p / 2}}
$$

onde $E_{p}$ representa o potencial de pico e $E_{p / 2}$, o potencial de Ip a meia altura (BARD et al, 2001).

Assim, o valor encontrado para $\left[(1-\alpha) n_{a}\right]$, utilizando-se para fins de cálculo o voltamograma obtido a $v=25 \mathrm{mV} \mathrm{s}^{-1}$ na presença de $1,00 \times 10^{-3} \mathrm{~mol} \mathrm{~L}^{-1}$ de AMT, similar àquele apresentado na Figura 1 (b), curva 2 , foi igual a 0,56 . Substituindo esse valor, além de todos os outros valores pertinentes, na equação (2), foi possível obter um valor de $n$ igual a 0,98 , sugerindo que o mecanismo de eletrooxidação de AMT sobre o GRF-SiAlNb-DNA envolve um elétron. Esse número de elétrons corrobora com dados determinados na literatura (DUARTE et al, 2014a).

A fim de comparação, a determinação dos parâmetros cinéticos referentes ao processo de eletroeletrooxidação da AMT frente ao DNA imobilizado, foi realizada, empregou-se o método proposto por Laviron (LAVIRON, 1979).

A literatura recomenda quando se tem o intuito de estudar a cinética de transferência de elétrons entre um catalisador, neste trabalho, o DNA imobilizado sobre a superfície do eletrodo e um analito-alvo (amitriptilina, neste caso) os seguintes parâmetros devem ser estimados: $\alpha$ (coeficiente de transferência de elétrons), $k$ (constante de velocidade de transferência de elétrons) e $n_{e}$ (número de elétrons) para reação de oxirredução entre o DNA imobilizado na superfície da SiAlNb e o analito alvo em solução.
A corrente de pico para espécies eletroativas é dada pela Equação 4 (CHEN et al., 2011):

$$
I_{p}=\frac{n e^{2} F^{2} v A \Gamma}{4 R T}
$$

Sendo que $I_{p}$ é a intensidade de corrente de pico, $F$ a constante de Faraday, $A$ a área do eletrodo, $v$ a velocidade de varredura, $\Gamma$ a quantidade de material biológico adsorvido sobre a superfície do material (SiAlNb) e incluída no compósito GRF-SiAlNb-DNA $\left(\mathrm{mol} \mathrm{cm} \mathrm{cm}^{-2}\right), R$ a constante dos gases, $T$ a temperatura e $n_{e}$ o número de elétrons participante na reação. $\mathrm{O}$ valor de $n_{e}$ pode ser determinado através da equação descrita acima, se os outros parâmetros forem conhecidos. Embora a Equação (4) seja a forma mais utilizada para calcular o numero de elétrons participantes de reações redox, a teoria demonstra que a largura de meia altura do pico, $\delta_{0,5}$, medida em milivolts $(\mathrm{mV})$ deve ser igual a $90,6 / \mathrm{n}$ para o caso ideal (LAVIRON, 1982). Esta metodologia proposta por Laviron é mais simples e sua aplicação é restrita às espécies adsorvidas, como ocorre neste caso estudado.

Estes estudos foram realizados em solução tampão fosfato $0,2 \mathrm{~mol} \mathrm{~L}^{-1} \mathrm{pH}$ 7,5 e foram determinados os valores de $k, \alpha$ e $n_{e}$ da catálise da AMT promovida pelo sensor. O sensor GRF-SiAlNb-DNA apresentou, em baixas velocidades de varredura $\left(15 \mathrm{mVs}^{-1}\right)$, na presença de $1,0 \times 10^{-3} \mathrm{~mol} \mathrm{~L}^{-1}$ de AMT, um $\delta_{0,5}$ em torno de $93 \mathrm{mV}$. Substituindo este valor de $\delta_{0,5}$ na expressão mencionada anteriormente, encontrou-se o valor de $\mathrm{n}$ igual a 0,97 eletrons para o sistema estudado. Desta forma, este resultado fortemente sugere que um elétron participa da reação redox, especialmente porque é conhecido que o mecanismo de oxidação da AMT e dos fármacos de sua classe envolvem apenas um elétron e um próton (ROMEIRO et al., 2003; TOLEDO at al., 2005).

Desta forma, demonstrou-se que o numero de elétrons envolvidos no processo redox estudado 
(eletrooxidação da AMT pelo DNA) é o mesmo por ambos os métodos aplicados, validando de certa forma a investigação do mecanismo reacional estudada.

É importante salientar que a imobilização do DNA neste tipo de matriz (sílica modificada com óxidos mistos) pode causar o bloqueio de alguns sítios catalíticos do DNA, refletindo num valor obtido de n (numero de elétrons) menor que o esperado. Embora este fenômeno possa ocorrer, o componente biológico (DNA) ainda apresentou capacidade de eletrooxidar o analito em estudo (AMT) conforme verificado na Figura 1B.

Outro ponto a ser considerado e que pode ocasionar a obtenção de valores de $n$ menores que o esperado é a alta resistência da matriz inorgânica, a qual é pouco condutora e pode dificultar a transferência de elétrons.

É importante mencionar neste ponto do trabalho que foi assumido que a espécie eletroativa (DNA) está adsorvida sobre o material inorgânico (SiAlNb), uma vez que o $\mathrm{Nb}_{2} \mathrm{O}_{5}$, age como um ácido de Lewis, promove uma excelente adsorção (interação ácido-base de Lewis) dos grupos básicos (bases nitrogenadas) presentes na estrutura do DNA (MARCO, et al., 2013) sobre a superfície deste material. Desta forma, o método empregado para o cálculo do número de elétrons envolvido no processo redox entre o DNA imobilizado sobre a sílica sol-gel e o analito em estudo (AMT) é idealmente aplicado quando a isoterma de Langmuir é obedecida, ou seja, a espécie eletroativa deve se encontrar adsorvida como uma monocamada, apresentando-se altamente dispersa na superfície da matriz inorgânica. Assim, foi empregada neste trabalho uma estimativa desta condição, uma vez que, o sistema obtido, constituído de pó de grafite (pasta de carbono), DNA imobilizado sobre a matriz inorgânica e o óleo mineral possui uma estrutura bastante complexa.

A influência do $\mathrm{pH}$ sobre o potencial de pico anódico (Epa) de AMT também foi verificada por voltametria cíclica, observando-se uma relação linear entre os referidos parâmetros na faixa de $\mathrm{pH}$ entre 6,0 e 8,5 (Figura 3).

$\mathrm{O}$ coeficiente angular desse gráfico $(0,059 \mathrm{~V} /$ $\mathrm{pH})$ é coincidente com o valor esperado para um sistema nernstiano $(0,0592(n p / n e) \mathrm{V} / \mathrm{pH})$, onde o $n p$ envolvidos na reação eletroquímica é igual ao ne (PAPOUCHADO et al 1975). Portanto, esse resultado sugere que no processo de oxidação de AMT sobre a superfície do sensor à base de DNA proposto o $n p$ é igual ao ne envolvidos.

Figura 3 - Influência do $\mathrm{pH}$ sobre o potencial de pico anódico (Epa) determinado em solução $1 \mathrm{mmol}$ $\mathrm{L}^{-1}$ de AMT. Medidas realizadas em solução $0,1 \mathrm{~mol}$ $\mathrm{L}^{-1}$ de tampão fosfato; $v=10 \mathrm{mV} \mathrm{s}^{-1}$.



Fonte: Os autores

O pico de oxidação apresentado na Figura 1 (b), curva 2, resulta da oxidação do analito em um processo de transferência de um elétron (TOLEDO et al., 2005) e assim, pode-se propor que o mecanismo de oxidação do analito sobre a superfície do sensor a base de DNA proposto ocorre conforme apresentado na Figura 4. É importante ressaltar que o presente trabalho está de acordo com a literatura (TOLEDO et al., 2005), uma vez que, neste trabalho há transferência de 1 elétron e a oxidação é dependente de próton, com perda de um elétron e 1 próton o que justifica o comportamento linear em função do $\mathrm{pH}$. 
Figura 4 - Possível mecanismo de oxidação da AMT sobre GRF-SiAlNb-DNA.



Fonte: Os autores

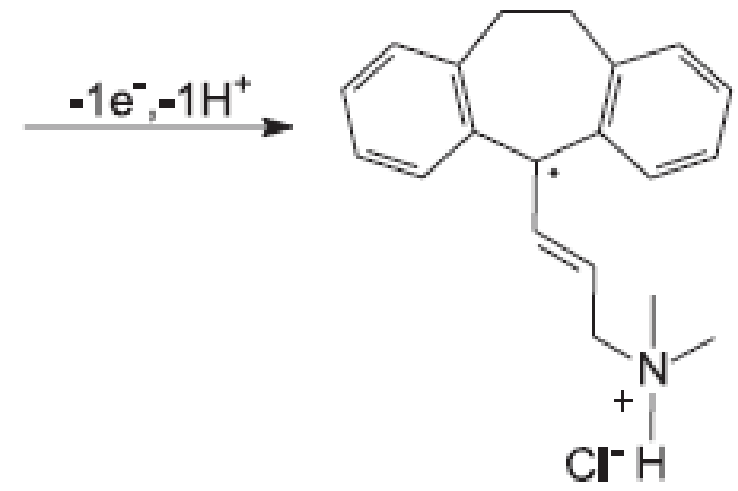

Ainda em relação aos estudos referentes ao processo de eletrooxidação de AMT frente ao compósito GRF-SiAlNb-DNA, um gráfico de função de corrente, $I p / \mathrm{v}^{1 / 2}$, (corrente normalizada pela raiz da velocidade de varredura) foi construído a partir dos dados de corrente de pico e velocidade de varredura. Desta forma, a Figura 5 apresenta o comportamento da interação entre o analito e o DNA imobilizado no GRF-SiAlNb-DNA. Conforme pode ser observado, o gráfico de função de corrente versus velocidade de varredura resultou em um típico perfil observado para sistemas EC' (Eletroquímico Químico Catalítico), no qual a função de corrente a baixas velocidades de varredura apresenta elevados valores e a altas velocidades de varredura a função de corrente converge para o coeficiente angular da curva $I p$ vs v ${ }^{1 / 2}$ (Figura 2).

Importante ressaltar que este resultado corrobora com aquele apresentado na Figura 1c, sugerindo que a oxidação do analito na presença do DNA ocorre por via catalítica.
Figura 5 - Relação entre a função de corrente $\left(\mathrm{Ipa} / \mathrm{v}^{1 / 2}\right)$ versus a velocidade de varredura para $1,0 \mathrm{mmol} \mathrm{L}^{-1}$ de AMT em solução $0,2 \mathrm{~mol} \mathrm{~L}^{-1}$ tampão fosfato $\mathrm{pH}$ 7,5 utilizando GRF-SiAlNbDNA.

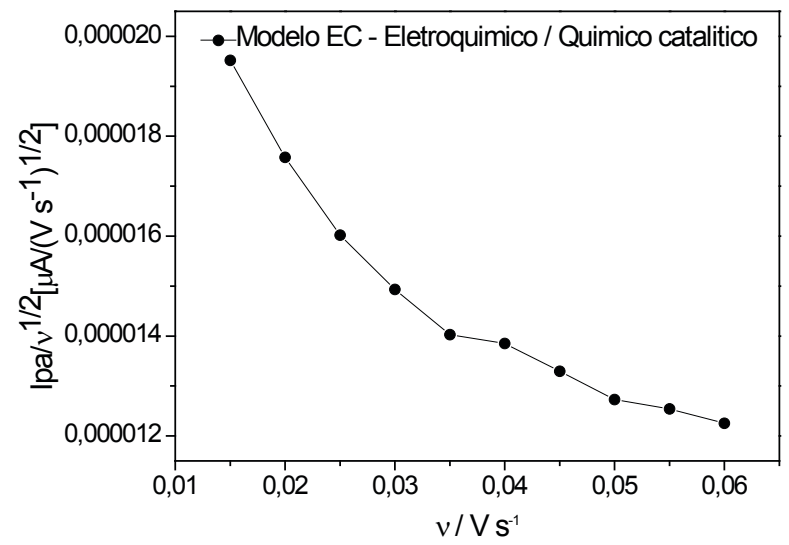

Fonte: Os autores

A Figura 6 ilustra as magnitudes dos potenciais de pico anódico em função do logaritmo da velocidade de varredura do potencial para o sistema estudado. 
Figura 6 - Gráfico de Laviron $\left(E_{p a} v s \log v / V_{s}{ }^{1}\right)$ para o pico anódico da AMT utilizando biossensor GRF-SiAlNb-DNA. Experimento realizado com 1 mmol L-1 de AMT em solução tampão fosfato 0,2 mol L-1 $\mathrm{pH} 7,5$.

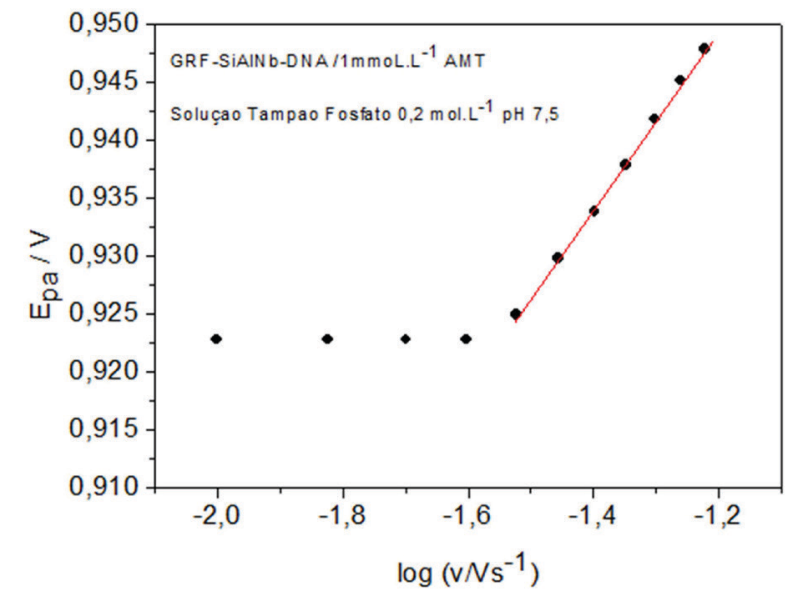

Fonte: Os autores

De acordo com a teoria, em elevados valores de velocidade de varredura, verifica-se uma dependência linear entre $E_{p a} \operatorname{com} \log \left(\mathrm{v} / \mathrm{Vs}^{-1}\right)$, de forma que é possível extrair os parâmetros cinéticos $\alpha$ anódico bem como $k$ a partir dos coeficientes lineares e angulares das curvas de Laviron.

O coeficiente angular para o segmento linear da curva de Laviron é $2.303 R T / \alpha_{a} n F$, para o pico anódico. Sendo que o coeficiente angular (para curva $\mathrm{Ep} / \mathrm{V}$ versus $\log \mathrm{v} / \mathrm{Vs}^{1}$ ) encontrado foi de 0,0783 . O valor de $a$ anódico obtido empiricamente foi de 0,75 considerando 1 elétron envolvido no processo de oxidação. Neste sentido, o valor de a igual a 0,75 para o processo de oxidação da AMT foi empregada para estimativa da constante de velocidade de transferência de elétrons $(k)$ conforme a Equação 5.

$$
K=\frac{\alpha_{c} n e F v_{c}}{R T}=\frac{\alpha_{a} n e F v_{a}}{R T}
$$

O valor de $k$ estimado para a catálise da AMT foi de 29,2 $\mathrm{s}^{-1}$. Este valor estimado para velocidade de varredura de $1 \mathrm{Vs}^{-1}$ em conjunto com o valor de $\alpha$, confirmando, conforme já mencionado que a eletrooxidação da AMT ocorre por um processo catalítico com elevada taxa de transferência de elétrons. Estes resultados são semelhantes ou melhores que outros trabalhos desenvolvidos utilizando biossensores para determinação de AMT (TOLEDO at al, 2005; BIRYOL et al., 1996). Por fim, é importante mencionar que o comportamento eletroquímico do fármaco investigado, de um modo geral, em relação ao $\mathrm{pH}$, processo difusional, viabilidade cinética, avaliada a partir de valores de constante de velocidade de transferência de elétrons $(k)$, entre outros é similar a outros sensores apresentados na literatura (DUARTE et al, 2014a; ESLAMI et al, 2014; BIRYOL et al, 1996; THARMARAJ et al., 2009 ).

\section{Conclusões}

Este trabalho demonstra que a modificação da superfície do eletrodo foi efetuada de forma simples e efetiva, proporcionando grande estabilidade ao dispositivo desenvolvido. O sensor GRF-SiAlNbDNA foi capaz de promover um processo de eletrooxidação eletrocatalítico do analito, evidenciado pelo aumento significativo da $I_{p a}$. Verificou-se que é importante o emprego simultâneo do pó de grafite e da SiAlNb-DNA para que ocorra a eletrooxidação eletrocatalítica de AMT. Tal eletrocatálise pode ser atribuída à baixa resistência de transferência de carga do compósito GRF-SiAlNb-DNA, bem como a uma melhor dispersão e fixação do DNA na superfície da sílica, quando esse é utilizado junto com o grafite em pó.

O processo eletrocatalítico da AMT frente ao DNA imobilizado sobre a superfície da matriz inorgânica caracterizou-se por ser um processo irreversível e controlado por difusão (de acordo com o perfil voltamétrico e relação de corrente anodica em função da velocidade de varredura), bem como dependente do $\mathrm{pH}$, sendo, nesse caso, determinado com transferência de um elétron e com viabilidade cinética para o processo redox (alta velocidade de transferência de elétrons). 
O valor de $k$ estimado para a catálise da AMT para velocidade de varredura de $1 \mathrm{Vs}^{-1}$ em conjunto com o valor de $\alpha$, sugerem que o processo é irreversível e com alta velocidade de transferência de elétrons para a reação de catálise eletroquímica entre o DNA e o analito, com resultados semelhantes ou melhores que outros trabalhos desenvolvidos e reportados na literatura utilizando sensores para determinação de AMT.

\section{Agradecimentos}

Os autores são gratos à Fundação de Amparo à Pesquisa do Estado de Minas Gerais (FAPEMIG), ao Conselho Nacional de Desenvolvimento Científico e Tecnológico (CNPq), à Coordenação de Aperfeiçoamento de Pessoal de Nível Superior (CAPES), ao INCT de Bioanalítica, à Fundação Araucária do Paraná, à Fundação Carlos Chagas Filho de Amparo à Pesquisa do Estado do Rio de Janeiro (FAPERJ) pelo apoio financeiro e bolsas de pesquisador, e ao estudante de iniciação científica Felipo Doval Rojas Soares do IQ/UFRJ pela preparação do material SiAlNb. Este trabalho é um projeto de colaboração entre os membros da Rede Mineira de Química (RQ-MG) financiado pela FAPEMIG.

\section{Referências}

ANDRIEUX, C. P.; SAVÉANT, J. M. Heterogeneous (Chemicallymodified electrodes, polymerelectrodes) vs. Homogeneous catalysis of electrochemical reactions. Journal of Electroanalytical Chemistry and Interfacial Electrochemistry, v. 93, p. 163-168, 1978.

BARD, A. J.; FAULKNER, L. R. Electrochemical methods: fundamentals and applications. 2. ed. New York: John Willey \& Sons, 2001.

BIRYOL, I.; USLU, B.; KÜÇÜKYAVUZ, Z. Voltammetric determination of imipramine hydrochloride and amitriptyline hydrochloride using a polymer-modified carbon paste electrode. Journal of Pharmaceutical and Biomedical Analysis, v. 15, p. 371-381, 1996.
BRETT, A. M. O.; MACEDO, T. R. A.; RAIMUNDO, D.; MARQUES, M. H.; SERRANO, S. H. P. Voltammetric behaviour of mitoxantrone at a DNA-biossensor. Biossensors and Bioelectronics, v. 13, p. 861-867, 1998.

CALISKAN, A.; ERDEM, A.; KARADENIZ, H. Direct DNA Hybridization on the Single-Walled Carbon Nanotubes Modified Sensors Detected by Voltammetry and Electrochemical Impedance Spectroscopy. Electroanalysis, v. 21, p. 2116-2124, 2009.

CHEN, P. Y.; LUO, C. H.; CHEN, M. C.; TSAI, F. J.; CHANG, N. A.; SHIH, Y. Screen-printed carbon electrodes modified with cobalt phtalocyanine for selective sulfur detection in cosmetics products. International Journal of Molecular Sciences, v. 12, p. 3810-3820, 2011.

COSTA, L. M.; RIBEIRO, E. S.; SEGATELLI, M. G.; NASCIMENTO, D. R.; OLIVEIRA, F. M.; TARLEY, C. R. T. Adsorption studies of $\mathrm{Cd}(\mathrm{II})$ onto $\mathrm{Al}_{2} \mathrm{O}_{3} /$ $\mathrm{Nb}_{2} \mathrm{O}_{5}$ mixed oxide dispersed on silica matrix and its on-line preconcentration and determination by flame atomic absorption spectrometry. Spectrochimica Acta. Part B, v. 66, p. 329-337, 2011.

DUARTE, E. H., GORLA, F. A., SARTORI, E. R.; TARLEY, C. R. T. Determinação voltamétrica de amitriptilina em formulações farmacêuticas com eletrodo de diamante dopado com boro explorando medidas em meio ácido. Quimica Nova, v. 37, n. 9, p. 1496-1502, 2014.

ESLAMI, E.; FARJAMI, F.; AZAR, P. A.; TEHRANI, M. S. Adsorptove Stripping Voltammetric Determination of Imipramine and Amitriptiline at a Nanoclay Composite Carbon Ionic Liquid Electrode. Electroanalysis, v. 26, p. 424-431, 2014.

LAVIRON, E. General expression of the linear potential sweep voltammogram in the case of diffusionless electrochemical systems. Journal of Electroanalytical Chemistry and Interfacial Electrochemistry, v. 101, p. 19-28, 1979.

Voltammetric methods for the study of adsorbed species. Journal of Electroanalytical Chemistry, v. 12, p. 53-157, 1982. 
MARCO, J. P.; BORGES, K. B.; TARLEY, C. R. T.; RIBEIRO, E. S.; PEREIRA, A. C. Development and application of an electrochemical biossensor based on carbon paste and silica modified with niobium oxide, alumina and DNA $\left(\mathrm{SiO}_{2} / \mathrm{Al}_{2} \mathrm{O}_{3} / \mathrm{Nb}_{2} \mathrm{O}_{5} /\right.$ DNA) for amitriptyline determination. Journal of Electroanalytical Chemistry, v. 704, p. 159-168, 2013.

PAPOUCHADO, L.; SANDFORD, R. W.; PETRIE, G.; ADMS, R. N. Anodic-oxidation pathways of phenolic compounds .2.stepwise electron transfers and coupled hydroxylations. Journal of Electroanalytical Chemistry and Interfacial Electrochemistry, v. 65, p. 275-284, 1975.

PAVAN, F. A.; RIBEIRO, E. S.; GUSHIKEM, Y. Congo Red Immobilized on a Silica/Aniline Xerogel: Preparation and Application as an Amperometric Sensor for Ascorbic Acid. Electroanalysis, v. 17, p. 625-629, 2005.

PEREIRA, A. C.; SANTOS, A. S.; KUBOTA, L. T. Tendências em modificação de eletrodos amperométricos para aplicações eletroanalíticas. Química Nova, v. 25, n. 6, p. 1012-1021, 2002.

ROMEIRO, L. A. S.; FRAGA, C. A. M.; BARREIRO, E. J. Novas estratégias terapêuticas para o tratamento da depressão: uma visão da química medicinal. Química Nova, v. 26, n. 3, p. 347-358, 2003.

SABIN, J.G.; FERRÃO, M.F.; FURTADO, J.C. Análise multivariada aplicada na identificação de fármacos antidepressivos. Parte II: Análise por componentes principais (PCA) e o método de classificação SIMCA. Brazilian Journal of Pharmaceutical Sciences, v. 40, p. 387-396, 2004.

THARMARAJ, P.; KODIMUNTHIRI, D.; SHEELA, C. D.; PRAKASH, P. Bis-(3,5-dimethylpyrazolyl-1-methyl)-(3-phosphanyl-propyl)-amine complexes of copper(II), nickel(II), and cobalt(II) Journal of coordination chemistry, v. 62, p. 13471355, 2009.

TOLEDO, R. A.; MAZO, L. H.; SANTOS, M. C.; HONÓRIO, K. M.; SILVA, A. B. F.; CAVALHEIRO, E. T. G. Estudo eletroquímico e químico-quantico da oxidação do antidrepressivo tricíclico amitriptilina. Química Nova, v. 28, n. 3, p. 456-461, 2005.
WANG, Z.; LIU, D.; DONG, S. In situ infrared spectroelectrochemical studies on adsorption and oxidation of nucleic acids at glassy carbon electrode. Bioelectrochemistry, v. 53, p. 175-181, 2001.

WEI, L.; YUNSONG, Z.; XIA, Z.; XIAOLI, H.; XIAOHUA, Z. An implified impedimetric DNA sensor based on graphene oxide-phenylboronic acid for sensitive detection of bleomycins. New Journal of Chemistry, v. 28, p. 2284-2291, 2014.

ZHENG, Y.; YANG, C.; PU, W.; ZHANG, J. Carbon nanotube-based DNA biossensor for monitoring phenolic pollutants. Microchimica Acta, v. 166, p. 21-26, 2009.
Recebido em 12 Abril, 2015 - Received on April 12, 2015 Aceito em 24 Agosto, 2015 - Accepted on August 24, 2015 